\title{
The Cultural Heritage of Tattooing: A Brief History
}

\author{
Lars Krutak
}

Repatriation Office, National Museum of Natural History, Smithsonian Institution, Washington, D.C., USA

\begin{abstract}
For millennia, peoples around the world have tattooed human skin to communicate various ontological, psychosocial, and sociocultural concepts encompassing beauty, cultural identity, status and position, medicine, and supernatural protection. As a system of knowledge transmission, tattooing has been and continues to be a visual language of the skin whereby culture is inscribed, experienced, and preserved in a myriad of specific ways. If we are to fully comprehend the meanings that tattoos have carried across human history and into the present, then it would be useful to explore some of the ways tattoos, as instruments that transmit culture, have been deployed cross-culturally through time.

c) 2015 S. Karger AG, Basel
\end{abstract}

\section{Adornment}

Across the indigenous world, tribal peoples rarely describe tattooing as an artistic or aesthetic practice because there are no terms for 'art' or 'artist' in the majority of indigenous languages. Instead, tattooing is integrated into the social fabric of community and religious life, and typically speaking, it is a cultural, clan, or family-mandated ritual that anchors societal values on the skin for all to see [1]. The tattooed dermis is a potent source of pride, precisely because it reenacts ancestral or mythological traditions. Wrapped in images of gods, ancestors, and spirits, tattoos have become venerated as symbols of protection, tribal unity, and genealogy.

However, it should be recognized that tattooing is sometimes used for beautification and is occasionally considered an artistic endeavor. Archaeological evidence indicates that the earliest tattoo, a 7,000-year-old tattooed mustache from South America, was cosmetic [2, 3]. Other anciently tattooed and mummified individuals from Nubia (ca. 2000 B.C.) and the Siberian Altai (3rd century B.C.) were adorned with ornamental tattoos that probably enhanced their sexuality and outward appearance [4]. In other locations, indigenous tattooists themselves have spoken about 
their indelible achievements. Alice Yaavgaghsiq, the last living Yupik tattooer of St. Lawrence Island, Alaska, approaches her tattooed creations the way a sculptor evaluates a piece of marble. When employing the timeworn technique of skin stitching, or needle and thread tattooing, Alice said: 'My designs came from my heart' [1].

\section{Identity}

Aesthetic considerations aside, the painful sensations and subsequent bloodletting associated with permanent body marking corresponds metaphorically to the process of being born, or rather, rebirth [5]. People gain new knowledge of themselves through painful stimuli like tattooing, and these sensate experiences model ways in which humans arrive at their ideas of existence and identity through imprinting new memories upon their consciousness and bodies [6].

In its traditional context, tattooing most often served to induct the recipient into indigenous society as a properly enculturated community member. As a rite of passage that belonged to the people, it also honored individual achievement and reinforced ancestral lineage ties through reenacting traditional ritual practices. But, it was not the physical manifestation of the tattoo on the body that was most important because the intangible meanings embodied in its creation, form, function, and associated history were of paramount concern. For example, on the Northwest coast of North America, clan crest tattoos were a primary vehicle through which collectivities demarcated their identities in the social milieu [1]. The origins of crests were tied to supernatural and mythic events, and these emblems were believed to embody the spirits of ancestors, some of whom were creatures of the land, sea, and air. Each crest, whether it was carved into an object or tattooed upon human skin, also embodied an intangible property, such as associated names, stories, songs, or even geographical locations, that belonged to the owner of the clan crest. The use of a clan crest set the group (clan) apart from others, while also defining its social position. Therefore, in Northwest Coast culture, the ownership of a crest, or the right to use the emblem, was more valuable than the possession of any physical object that might portray it, including a tattooed human body [1].

\section{Status and Position}

In many indigenous societies, tattoos were not applied by just anyone. The actual process was usually ritualized and performed by experts who were initiated and/or apprenticed into their position. Occasionally, the domain of tattooistry was reserved for priestesses, female aristocrats, healers, and shamans $[1,3,7]$.

The intrinsic value of tattooing, however, was not simply confined to the technical or performative aspects of the tattooist. Rather, the power of the tattooist often arose from deities or helper and ancestral spirits who channeled their supernatural agency into the tattooist. In Samoa, tattooing experts (tufuga tà tatau) were always male, and they participated in lengthy apprenticeships to earn a place in the guild of tattooers. These priestly men were compelled to honor patron deities and follow traditional rules and prohibitions; otherwise, their tattoos lacked mana, or spiritual potency [8]. On the Great Plains of North America, only tribal priests who were the keepers of sacred tattoo bundles derived from primordial beings could create tattoos [1]. These religious leaders were initiated into their ceremonial position and were required to purchase and learn the requisite tattoo rituals in order to perform them. Their clients included men who had proven themselves in battle through the performance of a series of ritually mandated acts that varied between tribes and aristocratic women of high birth, whose bodies were tattooed to activate life-giving' powers [1]. The cultural tradition of warrior 


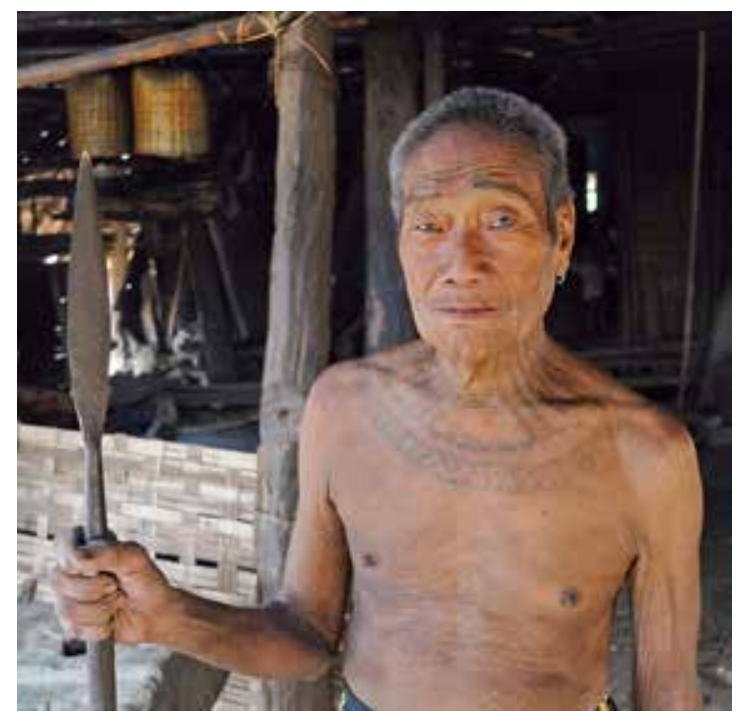

Fig. 1. Macham Naga tiger hunter U' Lum, 2014. (c) Lars Krutak.

tattooing, where tattoos were earned and not freely given, was also widespread across Asia, Africa, Melanesia, South America, and Polynesia [3, 7]. Among the Yimchungru Naga of India and the Macham and Ponyo Naga of Myanmar, 'warrior tattoos' were also earned for killing tigers [9] (fig. 1).

\section{Therapeutics}

The medicinal aspects of tattooing have largely been underreported. The mummified, tattooed remains of a Neolithic 'Iceman' discovered in Europe in 1991 are the oldest known human evidence of curative tattooing, which was akin to acupuncture. More than fifty bluish-black tattoos were placed at major joint articulations, and radiographic analyses of the Iceman's corpse revealed considerable arthrosis in many of the same regions (e.g., lower back or lumbar spine, hip joints, knee joints, and ankle joints) [10]. The 2,500-year-old tattooed mummy of a

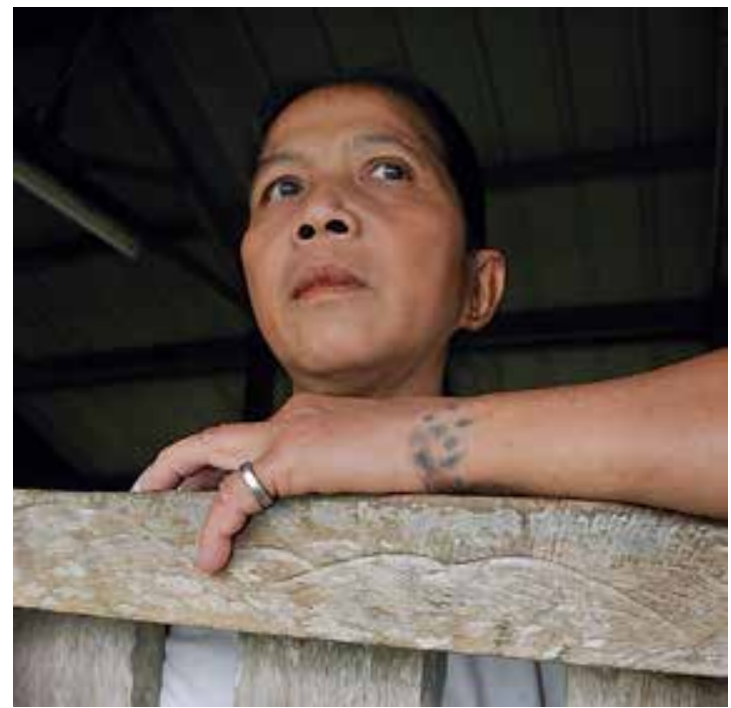

Fig. 2. Kayan therapeutic tattoos of Wen Meriang, 2011. (c) Lars Krutak.

tribal chieftain of the nomadic Pazyryk people of the Siberian steppes also displayed similar joint tattooing on his lower back and ankle joints [11]. In the historic period, the St. Lawrence Island Yupiit and Unangan (Aleut) of Alaska also practiced joint tattooing as a preventive against arthritic complaints and bodily pains $[1,3]$. Today, the therapeutic tradition of joint tattooing continues among the Kayan of Sarawak and closely resembles that of the Iceman in placement and function [10] (fig. 2).

The efficacy of tattooing as a medical technology was great because the indigenous Ainu of Japan, the Yuki and Miwok of California, and the Chippewa, Menominee, and Meskwaki of the Great Lakes region of North America also tattooed to relieve rheumatism and joint sprains [10].

Utilizing carboniferous pigments, the tattooing was performed directly over the painful location. The Chippewa also tattooed to cure goiter, as did several peoples of the northern Philippines $[10,12]$. Outside of these related cultural prac- 
tices, tattooing was documented in Native North America as a treatment for a variety of other medical complaints, including heart disease (Deg Hit'an), lack of mother's milk (Chugach Eskimo, Canadian Inuit), consumption (Miwok), and toothache (Iroquois) [1].

Experimental biomedical research conducted in the 1950s and 1960s suggested that infants and young children who were unusually stressed through traumatic hardening practices (e.g., piercing, circumcision, scarification, inoculation, head modeling, etc.) displayed more rapid rates in growth and overall size at adulthood, perhaps due to the stimulation of hormones secreted from the pituitary gland $[13,14]$. Belsky et al. [15] found that early childhood stress was also related to earlier onset of puberty. Studies in the 1990s concluded that individuals artificially stressed at the onset of puberty, which is another critical period in human development, also exhibited these and other biological benefits [16]. More recently, research has suggested that repetitive mild stress exposure has anti-aging effects and promotes longevity $[17,18]$. All of this reminds me of the many historical statements made by indigenous peoples who recognized the biological benefits of tattooing in early youth and at puberty, specifically that these tattooing practices promoted health, fertility, and long life $[1,3,19]$.

\section{Apotropaism and Mimicry}

Indigenous tattooists were often called upon by clients to apply preventive spiritual medicine upon their bodies via apotropaic tattoos. Spiritual possession and, even more so, being soul-less was greatly feared, and particular tattoo motifs were believed to repel the advances of malevolent spirits that infested the landscape $[3,7]$. Sometimes, however, the dynamic power of the tattoo was instead related to the use of magical pigments and sacred tools that pierced the dermis $[1,3]$. In other instances, the saliva of the tattooer was considered to embody supernatural power and was mixed with the tattooing pigment to neutralize or 'keep off evil spirits' from the tattooed client $[1,20,21]$.

Many tribal peoples believed that spirits resided in communities, just like those of humans. They had camps and villages, they married and hunted, and they had their own habits and characteristics in the form of culture [22, 23]. Spirits could also take human or semi-human form, and I see no reason why they were not tattooed just like humans. Thus, when humans were provided with 'apotropaic' symbols on their bodies, perhaps this form of tattooing was not, strictly speaking, protective. Instead, this variety of tattooing may originally have been incorporative or created to mimic the symbols believed to be worn by spirits. In this way, tattooed spirits would see tattooed humans as fellow spirits and not as prey [1].

\section{References}

1 Krutak L: Tattoo Traditions of Native North America: Ancient and Contemporary Expressions of Identity. Arnhem, LM Publishers, 2014.

2 Allison JM: Early mummies from coastal Peru and Chile; in Spindler K, Wilfring $\mathrm{H}$, Rastbichler-Zissernig E, Zur Nedden D, Nothdurfter H (eds): Human Mummies. A Global Survey of Their Status and the Techniques of Conservation 3. Vienna, Springer, 1996, pp 125-130.
3 Krutak L: The Tattooing Arts of Tribal Women. London, Bennett \& Bloom, 2007.

4 Renaut L: Tattooing in antiquity; in Anne \& Julien, Galliot S, Bagot P (eds): Tattoo. Paris, Musée du Quai Branly and Actes Sud, 2014, pp 22-26.

5 Gell A: Wrapping in Images: Tattooing in Polynesia. Oxford, Clarendon, 1993.

6 Jablonski NG: Skin: A Natural History. Berkeley, University of California Press, 2006.
7 Krutak L: Magical Tattoos and Scarification: Spiritual Skin. Aschaffenburg, Edition Reuss, 2012.

8 Galliot S: Samoan tattoos leave indelible global imprint. Voices 2011;27:10-11.

9 Krutak L: Tattooed tiger men of India and Myanmar. Total Tattoo 2013;106: 34-38. 
10 Krutak L: The power to cure: a brief history of therapeutic tattooing; in Della Casa P, Witt C (eds): Tattoos and Body Modifications in Antiquity. Zurich Studies in Archaeology 9. Zurich, Chronos Verlag, 2013, pp 27-34.

11 Krutak L: St. Lawrence Island joint-tattooing: spiritual/medicinal functions and inter-continental possibilities. Etud Inuit 1999;23:229-252.

12 Krutak L: Kalinga Tattoo: Ancient and Modern Expressions of the Tribal. Aschaffenburg, Edition Reuss, 2010.

13 Landauer TK, Whiting JWM: Infantile stimulation and adult stature of human males. Am Anthropol 1964;66:10071028.

14 Levine SJ: Stimulation in infancy. Sci Am 1960;202:80-86.
5 Belsky J, Steinberg L, Draper P: Childhood experience, interpersonal development, and reproductive strategy: an evolutionary theory of socialization. Child Dev 1991;62:647-670.

16 Ludvico LR, Kurland JA: Symbolic or not-so-symbolic wounds: the behavioral ecology of human scarification. Ethol Sociobiol 1995;16:155-172.

17 Gems D, Partridge L: Stress-response hormesis and aging: that which does not kill us makes us stronger. Cell Metab 2008;7:200-203.

18 Rattan SIS: Hormesis in aging. Ageing Res Rev 2008;7:63-78.
19 Dias J, Dias M: Os Macondes de Moçambique. Lisboa, Centro de Estudios de Antropologia Cultural, 1964.

20 Karsten R: Civilization of the South American Indians: With Special Reference to Magic and Religion. London, Kegan Paul, 1926.

21 Searight S: The Use and Function of Tattooing on Moroccan Women. 3 vols. New Haven, Human Relations Area Files, 1984.

22 Bogoras W: The Chukchee. Publications of the Jesup North Pacific Expedition 7; Memoirs of the American Museum of Natural History 11. New York, G.E. Stechert, 1904-1909.

23 Viveiros de Castro E: Cosmological deixis and Amerindian perspectivism. J R Anthropol Inst 1998;4:469-488.

Lars Krutak

Repatriation Office, National Museum of Natural History, Smithsonian Institution

10th \& Constitution Avenue NW, MRC 138, PO Box 37012

Washington, DC 20560 (USA)

E-Mail larskrutak@gmail.com 